\title{
Diachroneity of continental subduction and exhumation: Constraints from the Permian-Triassic HP metamorphic terrane in the Tongbai orogen, central China
}

\author{
LIU XiaoChun ${ }^{1 *}$, JAHN Bor-Ming ${ }^{2} \&$ LI SanZhong ${ }^{3}$ \\ ${ }^{1}$ Key Laboratory of Paleomagnetism and Tectonic Reconstruction of Ministry of Land and Resources, Institute of Geomechanics, \\ Chinese Academy of Geological Sciences, Beijing 100081, China; \\ ${ }^{2}$ Department of Geosciences, Taiwan University, Taipei 10699, Taiwan, China; \\ ${ }^{3}$ College of Marine Geosciences, Ocean University of China, Qingdao 266100, China
}

Received June 10, 2013; accepted July 16, 2013; published online September 3, 2013

\begin{abstract}
High-pressure (HP) metamorphic terrane in the Tongbai orogen comprises two HP slices (I and II) and a tectonic mélange zone in the northeast and a blueschist-greenschist zone in the southwest. HP slice I is represented by the northern and southern eclogite zones on the two sides of the Tongbaishan antiform. HP slice II is represented by retrograded eclogite-bearing metamorphic enclaves in Cretaceous gneissic granites in the Tongbai Complex. U-Pb, Lu-Hf, $\mathrm{Rb}-\mathrm{Sr}$ and ${ }^{40} \mathrm{Ar} /{ }^{39} \mathrm{Ar}$ multichronometric data indicate that the peak metamorphism of HP slice I took place at $255 \mathrm{Ma}$, whereas the metamorphic ages of HP slice II are as young as 232-220 Ma. By contrast, the tectonic mélange zone near the suture was metamorphosed at $\sim 256 \mathrm{Ma}$. Such a diachroneity of different slices across the direction of the orogen in the Hong'an-Dabie-Sulu HP/UHP terrane is ubiquitous, and it can be interpreted by a syn-subduction detachment/exhumation model. Furthermore, the metamorphic age of HP slice I in the Tongbai orogen is older than that of the equivalent HP slice in the Hong'an orogen by $\sim 15 \mathrm{Ma}$, suggesting that the diachroneity may have also existed along the direction of the orogen. A seesaw-type subduction/exhumation model is proposed to explain this age disparity and the subduction of the South China Block becomimg shallower towards the west.
\end{abstract}

Permian-Triassic, syn-subduction detachment/exhumation, seesaw-type subduction/exhumation, HP metamorphic terrane, Tongbai orogen

Citation: Liu X C, Jahn B M, Li S Z. Diachroneity of continental subduction and exhumation: Constraints from the Permian-Triassic HP metamorphic terrane in the Tongbai orogen, central China. Chin Sci Bull, 2013, 58: 4397-4404, doi: 10.1007/s11434-013-6067-9

The processes and mechanism of exhumation of ultrahighpressure (UHP) metamorphic rocks to the Earth's surface from mantle depths exceeding $\sim 100 \mathrm{~km}$ remain as one of the most difficult problems in earth science. It appears that a simple mechanism involving buoyancy and erosion is unable to explain the rapid exhumation required for the preservation of coesite. Much attention should be paid to the deepseated tectonic processes of continental slab. Based on the nature of structural contacts and existence of metamorphic gaps between different HP/UHP metamorphic units in the Dora Maira Massif of the western Alps, Chopin [1] and

*Corresponding author (email: liuxchqw@cags.ac.cn; liuxchqw@yahoo.com.cn)
Schreyer [2] inferred that the end of the downgoing slab might have successively broken to several slices during its subduction along very low geothermal gradients $\left(\sim 7^{\circ} \mathrm{C} / \mathrm{km}\right)$. The earlier subducted slices could be uplifted as the overlying hanging-walls during the subduction of the later underlying slices. Liu and $\mathrm{Hu}$ [3] have formerly noticed the similarity of HP/UHP terrane from the Dabie Mountains and the Dora Maira Massif. Lately Liu et al. [4,5] distinguished UHP, HP and low-temperature (LT) HP slices and a tectonic mélange zone with the time difference of exhumation of $\sim 30 \mathrm{Ma}$ in the Hong'an orogen on the basis of thermobaric structure and geochronological data, and proposed a diachronous subduction/exhumation model for the formation of 
different HP/UHP slices. Similarly, three HP/UHP slices with different peak metamorphic ages were also recognized in the Dabie-Sulu orogen in the light of precise isotopic dating, and multi-slice or differential subduction/exhumation model was established accordingly [6-12]. It seems that the idea of differential subduction and exhumation of continental slab has been generally accepted for the formation and evolution of the UHP terranes in China [12].

The Tongbai orogen is located in a key tectonic position linking the Qinling orogen to the west and the Hong'anDabie-Sulu orogen to the east. Unlike the Hong' an-DabieSulu orogen, this orogen has received little attention because of the absence of UHP rocks. We recently undertook petrological and geochronological studies on the Tongbai orogen, and identified diachronous subduction and exhumation between different medium-pressure (MP) and HP slices [13-15]. Furthermore, a comparative study of the Tongbai orogen with the Hong' an orogen also revealed a diachroneity along the same MP/HP slices. Our findings provide new constraints on the processes and mechanism of HP/UHP rocks. In this paper we briefly summarize the diachronous characteristics of the Tongbai HP metamorphic terrane, and propose possible models for the diachroneity across and along the directions of the orogen.

\section{Diachroneity of the Tongbai HP metamorphic terrane}

The Tongbai HP metamorphic terrane comprises two HP slices (I and II) and a tectonic mélange zone in the northeast and a blueschist-greenschist zone in the southwest (Figure 1). The tectonic mélange zone is separated from the Nanwan Devonian flysch and the northern eclogite zone by two NEdipping faults. It consists mainly of muscovite-albite gneisses, muscovite-quartz schists and greenschists, with strongly elongated metagabbro and metagranodiorite blocks. Metamorphism of the tectonic mélange zone only reached greenschist facies conditions. However, except large metagabbro and metagranodiorite blocks, all the rocks have undergone strong ductile shear deformation and formed diverse mylonites or mylonitic rocks. Since zircon U-Pb age data obtained for the equivalent unit in the Hong' an orogen are concentrated in the Neoproterozoic, it is generally accepted that the tectonic mélange zone represents a crustal segment of the South China Block [5,16-18]. Huang et al. [19] obtained a muscovite ${ }^{40} \mathrm{Ar}{ }^{39} \mathrm{Ar}$ age of $256 \pm 1$ Ma in the ductile shear zone and interpreted it as the time of deformation. This tectonic mélange zone appears to be comparable with the Luzhenguan complex in the Dabie orogen in terms of similar rock associations, metamorphism and deformation.

HP slice I is represented by the northern and southern eclogite zones on the two sides of the Tongbaishan antiform. It comprises granitic mylonites, muscovite-albite gneisses, muscovite-quartz schists, quartzites and marbles, with nu- merous eclogite and garnet amphibolite bands, lenses and blocks. Using conventional geothermometers and geobarometers, the peak metamorphic conditions were estimated to be 530-610 ${ }^{\circ} \mathrm{C}$ and 1.7-2.0 $\mathrm{GPa}$ for the northern zone and $460-560^{\circ} \mathrm{C}$ and 1.3-1.9 $\mathrm{GPa}$ for the southern zone [13]. These are roughly in agreement with the $P$ - $T$ estimates of $490-540^{\circ} \mathrm{C}$ and $1.8-2.1 \mathrm{GPa}$ using the THERMOCALC calculations [20]. Taking into account the similarity of rock associations and difference in metamorphic conditions between the two zones, we infer that they may belong to the different portion of the same HP slice. Two zircon U-Pb ages of $255 \pm 6 \mathrm{Ma}$ and $257 \pm 16 \mathrm{Ma}$, two garnet-whole rock Lu-Hf isochron ages of $252.3 \pm 3.4 \mathrm{Ma}$ and $256.4 \pm 2.6 \mathrm{Ma}$, and one mineral-whole rock $\mathrm{Rb}-\mathrm{Sr}$ isochron ages of $253 \pm$ $11 \mathrm{Ma}$ were obtained for eclogites from the HP slice I $[13,20]$. Since inclusions of garnet, omphacite, amphibole, paragonite, epidote, quartz and rutile were found in metamorphic zircon domains, and omphacite occur as inclusions in garnet, the age of $\sim 255 \mathrm{Ma}$ was regarded as the timing of eclogite facies metamorphism. On the other hand, muscovite ${ }^{40} \mathrm{Ar} /{ }^{39} \mathrm{Ar}$ dating for 3 muscovite-albite gneisses and 1 quartzite surrounding eclogites yielded ages of $238 \pm 2 \mathrm{Ma}$, $238 \pm 2 \mathrm{Ma}, 234 \pm 2 \mathrm{Ma}$ and $217 \pm 1 \mathrm{Ma}$, respectively [13], which reflects the time of muscovite cooling through its closure temperature of $\sim 350^{\circ} \mathrm{C}$.

HP slice II is represented by the metamorphic enclaves in the Tongbai Complex. The Tongbai Complex constitutes the core of the Tongbaishan antiform. To the northeast it is separated by a sinistral ductile fault from the northern eclogite zone, and to the southwest by a dextral ductile fault from the southern eclogite zone. The majority of the Tongbai Complex is strongly deformed coarse-grained granites, which make up $\sim 80 \%$ of the complex. The metamorphic enclaves on varying scales consist of fine-grained TTG gneisses and subordinate amphibolites, paragneisses, calcsilicates and marbles, with a few retrograded eclogite lenses. The conventional thermobarometries yielded $P$ - $T$ conditions of $660-700^{\circ} \mathrm{C}$ and $0.80-1.03 \mathrm{GPa}$ for the retrograde amphibolite facie metamorphic stage, whereas the peak metamorphic conditions were inferred to be within the eclogites facies field at $<700^{\circ} \mathrm{C}$ and $>1.2 \mathrm{GPa}$ [14]. Zircon U-Pb geochronology for retrograded eclogites, garnet amphibolites and dioritic-trondhjemitic gneisses reveals a long-term magmatism from $933 \pm 22$ Ma to $742 \pm 30 \mathrm{Ma}$, and metamorphic ages ranging from $232 \pm 6 \mathrm{Ma}$ to $220 \pm 3 \mathrm{Ma}$ [14]. The coarse-grained gneissic granites dominating the Tongbai Complex were dated at $\sim 140 \mathrm{Ma}$. On the other hand, ${ }^{40} \mathrm{Ar} /$ ${ }^{39} \mathrm{Ar}$ thermochronology on hornblende, muscovite and biotite from diverse gneisses and amphibolites yielded two age groups at 135-119 Ma and 99-92 Ma [21-23], implying that the Tongbai Complex may have involved two episodes of heating during the Cretaceous extension.

The blueschist-greenschist zone is located in the southwest of the southern eclogite zone, bounded by a ductile shear zone. To the southwest it is in contact with the South 


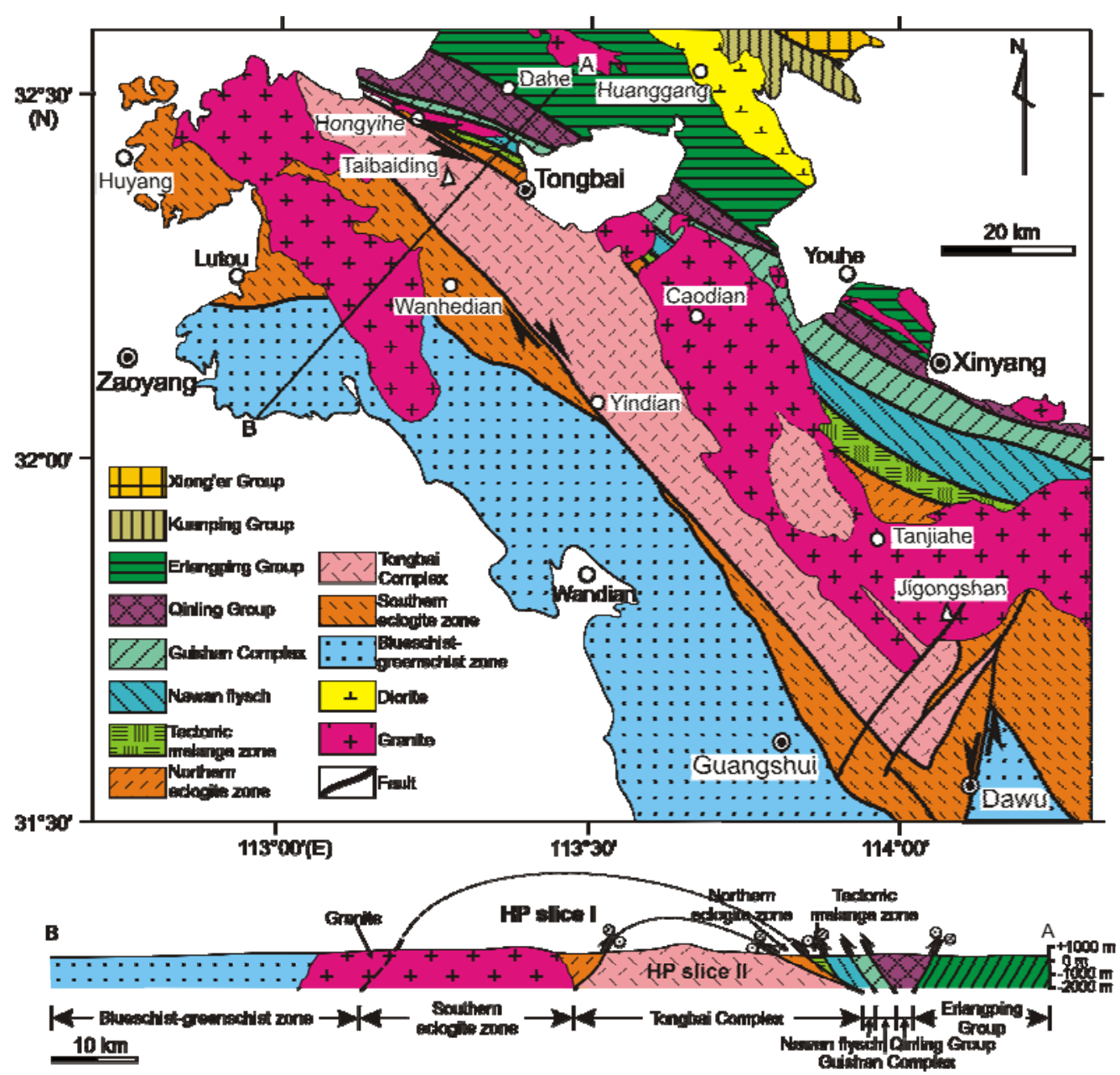

Figure 1 Simplified geological map of the Tongbai orogen and a generalized profile (A-B) across the orogen (modified after Liu et al. [14]).

China Block by the Xiangfan-Guangji fault. The lower part of the blueschist-greenschist zone is dominated by metamorphosed Neoproterozoic bimodal volcanic rocks with some metasedimentary rocks, whereas the upper part is mainly composed of interbedded greenschists, muscovite schists, muscovite-quartz schists and marbles. These two parts constitute a wide and gentle synclinal structure. The $P-T$ conditions of blueschist facies metamorphism were estimated to be $350^{\circ} \mathrm{C}$ and $0.7 \mathrm{GPa}$, and the transition of metamorphism from blueschist facies to greenschist facies were widely observed [24]. The metamorphic age of the blueschistgreenschist zone has not yet obtained in the Tongbai orogen. However, a phengite ${ }^{40} \mathrm{Ar} /{ }^{39} \mathrm{Ar}$ age of $231 \pm 1$ Ma was reported from its equivalent part in the Hong' an orogen [25].

\section{Interpretation of diachroneity across the direction of the orogen: A syn-subduction detachment/exhumation model}

The age of $\sim 255$ Ma obtained for HP slice I marks the oldest date of HP metamorphism in the Tongbai-Hong'an-
Dabie-Sulu orogen. This signifies that the onset of continental subduction and subsequent continent-continent collision between the North and South China Blocks were not later than Late Permian. The conclusion is supported by the following two facts. (1) The garnet-whole rock Lu-Hf and $\mathrm{Sm}-\mathrm{Nd}$ isochron ages of the oceanic-type eclogites from Xiongdian and adjacent area in the Hong'an orogen are concentrated to 271-252 Ma [26-29], which are later than the metamorphic zircon $\mathrm{U}-\mathrm{Pb}$ ages of $\sim 315 \mathrm{Ma}$ obtained for the same eclogites [27,30-32]. This suggests that these Carboniferous oceanic-type eclogites may have been reworked by continental subduction during the Late Permian. (2) A muscovite ${ }^{40} \mathrm{Ar} /{ }^{39} \mathrm{Ar}$ age of $261.5 \pm 1.6 \mathrm{Ma}$ is obtained for a metapsammite (sample XY24-1; 31 ${ }^{\circ} 59^{\prime} 52^{\prime \prime} \mathrm{N}, 114^{\circ} 05^{\prime} 02^{\prime \prime} \mathrm{E}$ ) from the Nanwan flysch of the Tongbai orogen (Table 1, Figure 2). This age is in agreement with muscovite ${ }^{40} \mathrm{Ar} /$ ${ }^{39} \mathrm{Ar}$ ages (271-261 Ma) obtained from the Foziling Group of the Dabie orogen [33-35]. These two Devonian flysch sequences may represent the hangingwall accretionary complex formed during the northerly subduction of the South China Block in the latest Paleozoic [36-38]. Considering that the metamorphic ages of 340-310 Ma for the Guishan 
Table 1 Muscovite ${ }^{40} \mathrm{Ar} /{ }^{39} \mathrm{Ar}$ analyses for metapsammite (sample XY24-1) from the Nanwan flysch ${ }^{\text {a) }}$

\begin{tabular}{rrrllllllllll}
\hline Step & $T\left({ }^{\circ} \mathrm{C}\right)$ & $\left({ }^{40} \mathrm{Ar} r^{39} \mathrm{Ar}\right)_{\mathrm{m}}$ & $\left.{ }^{(36} \mathrm{Ar}{ }^{39} \mathrm{Ar}\right)_{\mathrm{m}}$ & $\left({ }^{37} \mathrm{Ar}{ }^{39} \mathrm{Ar}\right)_{\mathrm{m}}$ & $\left({ }^{38} \mathrm{Ar}{ }^{39} \mathrm{Ar}\right)_{\mathrm{m}}$ & ${ }^{40} \mathrm{Ar}(\%)$ & $F$ & $\begin{array}{c}{ }^{39} \mathrm{Ar} \\
\left(\times 10^{-14} \mathrm{~mol}\right)\end{array}$ & $\begin{array}{c}{ }^{39} \mathrm{Ar}(\mathrm{Cum} .) \\
(\%)\end{array}$ & $\begin{array}{c}\mathrm{Age} \\
(\mathrm{Ma})\end{array}$ & $\begin{array}{c} \pm 1 \mathrm{~s} \\
(\mathrm{Ma})\end{array}$ \\
\hline 1 & 700 & 17.8654 & 0.0096 & 0.0000 & 0.0141 & 84.01 & 15.009 & 0.31 & 0.53 & 209.9 & 3.8 \\
2 & 800 & 20.0199 & 0.0051 & 0.0594 & 0.0142 & 92.52 & 18.524 & 1.13 & 2.48 & 255.6 & 2.5 \\
3 & 850 & 19.3101 & 0.0011 & 0.0000 & 0.0125 & 98.27 & 18.976 & 2.84 & 7.37 & 261.5 & 2.4 \\
4 & 900 & 19.3174 & 0.0010 & 0.0000 & 0.0125 & 98.43 & 19.015 & 8.77 & 22.49 & 262.0 & 2.4 \\
5 & 950 & 19.0761 & 0.0004 & 0.0033 & 0.0124 & 99.34 & 18.949 & 16.30 & 50.60 & 261.1 & 2.4 \\
6 & 980 & 19.0711 & 0.0004 & 0.0005 & 0.0123 & 99.38 & 18.952 & 5.39 & 59.90 & 261.2 & 2.4 \\
7 & 1020 & 19.1622 & 0.0008 & 0.0170 & 0.0125 & 98.77 & 18.926 & 3.22 & 65.45 & 260.8 & 2.4 \\
8 & 1060 & 19.1930 & 0.0009 & 0.0154 & 0.0125 & 98.64 & 18.932 & 4.01 & 72.37 & 260.9 & 2.4 \\
9 & 1100 & 19.1164 & 0.0004 & 0.0107 & 0.0124 & 99.35 & 18.992 & 6.92 & 84.31 & 261.7 & 2.4 \\
10 & 1140 & 19.1292 & 0.0003 & 0.0176 & 0.0124 & 99.55 & 19.043 & 7.66 & 97.52 & 262.3 & 2.4 \\
11 & 1180 & 19.1687 & 0.0005 & 0.0000 & 0.0123 & 99.20 & 19.015 & 1.32 & 99.80 & 262.0 & 2.5 \\
12 & 1300 & 21.3820 & 0.0017 & 0.2287 & 0.0142 & 97.66 & 20.886 & 0.12 & 100.00 & 285.8 & 8.6 \\
\hline
\end{tabular}

a) $\mathrm{The}^{40} \mathrm{Ar} /{ }^{39} \mathrm{Ar}$ analyses of muscovite were carried out using stepwise incremental heating at the Institute of Geology, Chinese Academy of Geological Sciences. The lower case letter " $\mathrm{m}$ " represents the measured isotopic ratios. Sample mass $(\mathrm{W})=29.60 \mathrm{mg} ; J$-value $=0.008219 ; F={ }^{40} \mathrm{Ar}^{*} /{ }^{39} \mathrm{Ar}$.

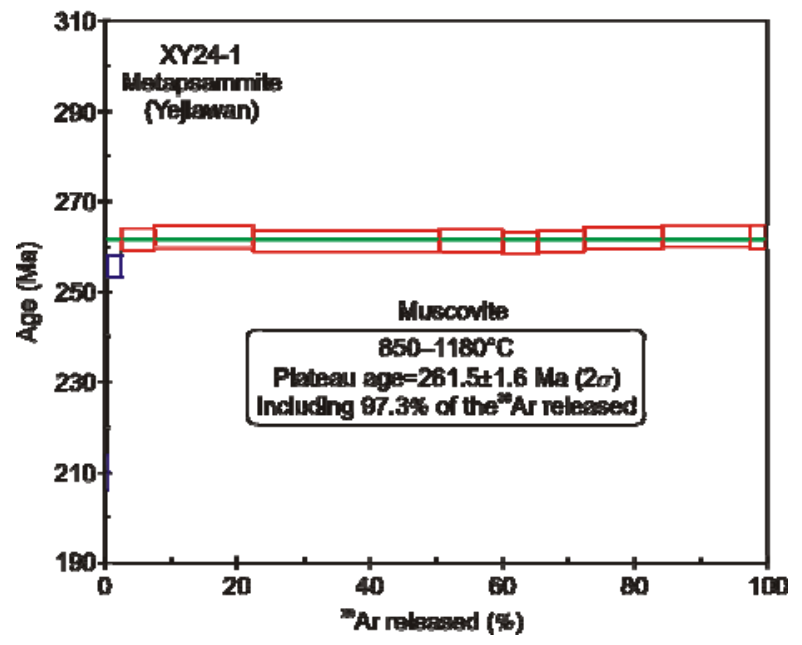

Figure 2 Muscovite ${ }^{40} \mathrm{Ar} /{ }^{39} \mathrm{Ar}$ plateau age spectra for metapsammite from the Nanwan flysch.

complex [39] are comparable with those of the Xiongdian eclogites, we infer that the oceanic subduction prior to the final collision between the North and South China Blocks may have lasted for $\sim 60 \mathrm{Ma}$ (Figure 3(a), (b)).

More importantly, the muscovite ${ }^{40} \mathrm{Ar} /{ }^{39} \mathrm{Ar}$ cooling age of HP slice I is $\sim 238 \mathrm{Ma}$, which is older than the metamorphic age (232-220 Ma) of HP slice II. This suggests that, when HP slice II was subducted to deep levels and underwent HP metamorphism, the overlying HP slice I had probably been exhumed to middle to upper crustal levels. It is obvious that the subducted continental crust was detached at deep levels. $\mathrm{Pb}$ isotopic geochemical study indicates that the $\mathrm{Pb}$ isotopic compositions of HP slice II are more radiogenic than those from the Northern Dabie Complex, but less radiogenic than those from the Central Dabie UHP zone [40], roughly equiv- alent to those of mid-crustal rocks. Therefore, the detachment of HP slices I and II may occur between the middle and upper crusts. On the other hand, the muscovite ${ }^{40} \mathrm{Ar} /$ ${ }^{39} \mathrm{Ar}$ age of $256 \pm 1 \mathrm{Ma}$ was obtained for the greenschist facies tectonic mélange zone north of HP slice I [19], suggesting that this low-grade metamorphic unit represents another mixed slice derived from both Neoproterozoic basement complex of the south China Block and Paleozoic volcanic rocks of the northern Qinling terrane [41]. This mixed slice took its place at a shallow level during the subduction of HP slice I. As mentioned previously, syn-subduction detachment and exhumation of HP/UHP slices have been widely recognized in the Hong'an-Dabie-Sulu orogen $[8,12]$. However, it seems that the detachment of continental slab at middle to lower crustal levels is especially prominent in the Tongbai orogen. Based on the continental subduction channel model [42], the crustal slices detached at different depths could enter into the subduction channel during the subduction of continental lithosphere. These crustal slices would undergo metamorphism and deformation in varying degrees and then successively exhumed along the subduction channel. Therefore, syn-subduction detachment and exhumation might be a major mechanism for the preservation and uplifting of HP/UHP rocks in the Tongbai-Hong'an-DabieSulu orogen (Figure 3(b),(c)). The final exposure of these rocks on the surface is ascribed to the Early Cretaceous extensional event (Figure 3(d)) [23].

The LT/HP blueschist-greenschist zone south of HP slice I could extend continuously eastward to the Hong' an-Dabie orogen. The metamorphic volcanic-sedimentary rocks with a better sequence in this zone may represent surficial rocks deposited on the northern margin of the South China Block. These rocks structurally show south-dipping in the Hong'an orogen [4] and top-to-the-south thrusting in the Tongbai 


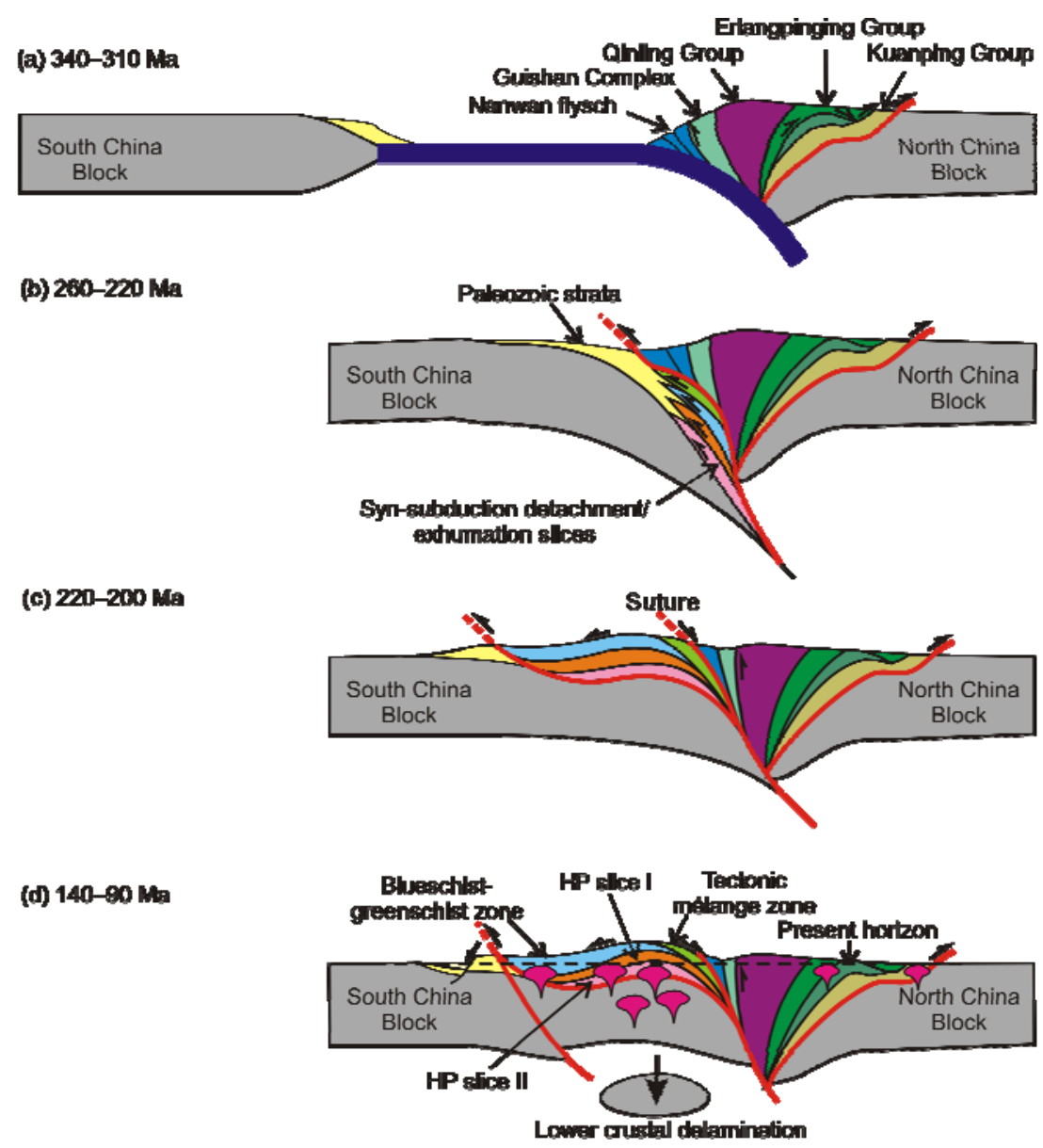

Figure 3 Tectonic evolution of the Tongbai orogen from oceanic subduction/accretion to continental collision during the Late Paleozoic to Mesozoic (modified after Liu et al. [38]).

orogen [43]. Therefore, the blueschist-greenschist zone was regarded as a large-scale nappe extruded from the northern suture in our tectonic model [5,38]. In fact, this LT/HP zone should represent an earlier detached slice. However, because the equivalent metamorphic rocks were not observed near the suture, it is difficult to determine its positional relationship with other MP/HP slices. We positioned it on HP slices I due to the direct contact and the fitness of rock associations and metamorphic environment between them. Obviously, this assumption needs to be verified by geochronological dating.

\section{Interpretation of diachroneity along the direction of the orogen: A seesaw-type subduction/exhumation model?}

It is generally considered that the Tongbai HP metamorphic terrane is the westward continuation of the Hong'an-Dabie HP/UHP metamorphic terrane. In addition to the absence of a UHP metamorphic zone, the major tectonic units (i.e. slices) in the Tongbai orogen correspond one-to-one to those in the Hong'an-Dabie orogen. However, the precise isotopic dating also reveals a difference of metamorphic ages in the same slice between the two areas. As previously stated, the metamorphic age of HP slice I in the Tongbai orogen is $\sim 255 \mathrm{Ma}[13,20]$. Whilst metamorphic zircon grains from amphibolite and quartz-rich leucosome from the Huwan eclogite zone in the Hong'an orogen, which is equivalent to the northern eclogite zone in the Tongbai orogen, yielded ${ }^{206} \mathrm{~Pb} /{ }^{238} \mathrm{U}$ ages of $243 \pm 4 \mathrm{Ma}$ and $241 \pm 1 \mathrm{Ma}$, respectively [44]. These zircon grains contain inclusions of garnet and omphacite, and show flat HREE patterns with weak negative Eu anomalies, suggesting that they formed at eclogite facies conditions. Similarly, three garnet-whole rock Lu-Hf isochron ages of $243.3 \pm 4.1 \mathrm{Ma}, 240.7 \pm 1.2 \mathrm{Ma}$ and 238.3 \pm 1.2 Ma were obtained from the Hong'an eclogite zone [45], which is equivalent to the southern eclogite zone in the Tongbai orogen. Apparently, HP slice overlaying UHP slice in the Hong'an orogen should have formed at $\sim 240 \mathrm{Ma}$, postdating HP slice I in the Tongbai orogen by $\sim 15 \mathrm{Ma}$. The muscovite ${ }^{40} \mathrm{Ar} /{ }^{39} \mathrm{Ar}$ age obtained from the Balifan tectonic mélange zone north of the Huwan eclogite zone is $242 \pm 2 \mathrm{Ma}$ [25], also younger than that of the equivalent slice in the Tongbai orogen by $\sim 15 \mathrm{Ma}$. This suggests that the diachroneity may have also existed at least in 
non-UHP slices along the direction of the Tongbai-Hong' an orogen.

Two groups of zircon U-Pb ages of 245-240 Ma and 225-220 Ma are common for UHP metamorphic rocks from the central and southern Dabie orogen [46-49]. The former was generally interpreted as the age of metamorphic dehydration event occurring in the transition from HP to UHP conditions during continental subduction, and the latter as the age of metamorphic dehydration event in the transition from UHP to HP conditions during the exhumation of deeply subducted continental crust $[42,50]$. The peak UHP metamorphism in the diamond stability field may have took place at 238-235 Ma [12]. In contrast, UHP metamorphism in the northern Dabie orogen occurred at ages as young as 226-214 Ma [7,51]. The Northern Dabie Complex shows typical structural characteristics of metamorphic core complexes [52], which could be comparable with the Tongbai Complex. The reconstruction of crustal architecture of the Dabie orogen indicates that, during the Triassic continental subduction, the Northern Dabie UHP slice underlay the Central Dabie UHP slice, and the Southern Dabie UHP slice overlay the Central Dabie UHP slice [53,54]. In comparison with the Northern Dabie UHP slice, HP slice II in the Tongbai orogen shows lower metamorphic $P-T$ conditions [14], but the peak metamorphic ages are pretty much the same.

How to understand the diachroneity of metamorphism for some of the same slices along the direction of the orogen? One possible interpretation is that the passive margin of the South China Block is irregular; hence the continental collision and accompanying metamorphism may occur diachronously in different areas. We can assume that the collision between the North and South China Blocks during the Late Permian to Triassic commenced at $\sim 255 \mathrm{Ma}$ in the Tongbai area. Towards the east the age of final closure of intercontinental basin is later than the onset by $\sim 15 \mathrm{Ma}$. This essentially fits an anticlockwise scissor-type diachronous collision model, which is different from the clockwise scissortype diachronous collision model established for the Qinling-Tongbai-Hong'an-Dabie-Sulu orogenic belt on the basis of paleomagnetic data [55,56]. However, if this assumption is correct, HP slice in the Tongbai and Hong'an areas would not be the same slice proper, but truly two detached slices with similar geological features. If HP slice in two areas is the same slice proper, the diachroneity along the direction of the orogen could be interpreted by a seesawtype subduction/exhumation model. It is inferred that, when the western part of HP slice in the Tongbai area was subducted to deep levels and underwent HP metamorphism at $\sim 255 \mathrm{Ma}$, the eastern part of the same slice in the Hong'an area was also positioned at shallow levels. Subsequently, when the eastern part was subducted to deep levels and underwent HP metamorphism at $\sim 240 \mathrm{Ma}$, the western part might have been exhumed to middle to upper crustal levels and cooled to below $\sim 350^{\circ} \mathrm{C}$. Likewise, the western and eastern parts of the tectonic mélange zone in the Tongbai and Hong' an areas were perched at shallow levels at 255 Ma and $240 \mathrm{Ma}$, respectively. The seesaw-type subduction/exhumation of the same slices may be triggered by a gradual steepening of the subducted slab towards the east. This model can also explain why the subduction of the South China Blocks becomes shallower towards the west and the absence of UHP rocks in the Tongbai orogen [14]. However, the diachroneity along the direction of HP/UHP slices became indistinct during the late stage of continental subduction/collision. At this period the continental slab might have only maintained subduction style with shallowing in the west and deeping in the east, but without age disparity.

\section{Conclusions}

The diachronous exhumation of the subducted continental slab is one of the most important features of the TongbaiHong' an-Dabie-Sulu HP/UHP metamorphic terrane. Such a process could have worked for other large HP/UHP metamorphic belts, such as, the Dora Maira Massif of the western Alps. The syn-subduction detachment/exhumation model can reasonably explain the difference of metamorphic ages between different HP/UHP slices in the Hong'an-DabieSulu orogen. The age spectra of HP metamorphic terrane in the Tongbai orogen provide further evidence supporting this model. Furthermore, it seems that the diachroneity also exists in the same slice along the direction of the orogen. This may be important for understanding the processes and mechanism of subduction and exhumation of HP/UHP rocks. In this paper, we tentatively propose a seesaw-type subduction/exhumation model to interpret this along-strike diachroneity. However, the relations between this model and continental channel model need to be further investigated.

We sincerely thank Profs. Yong-Fei Zheng and Wei Lin for critical reviews and editorial comments. Particularly Yong-Fei Zheng contributes some additional discussion on the primary manuscript. This work was supported by the National Basic Research Program of China (2009CB825006).

1 Chopin C. Very-high-pressure metamorphism in the West Alps: Implications for subduction of continental crust. Phil Trans R Soc Lond, 1987, A321: 183-197

2 Schreyer W. Subduction of continental crust to mantle depths: Petrological evidence. Episodes, 1988, 11: 97-104

3 Liu X C, Hu K. Ultra-high-pressure metamorphism. Geol Sci Tech Inform, 1991, 10: 17-23

4 Liu X C, Wei C J, Li S Z, et al. Thermobaric structure of a traverse across western Dabieshan: Implications for collision tectonics between the Sino-Korean and Yangtze cratons. J Metamorph Geol, 2004, 22: 361-379

5 Liu X C, Jahn B M, Liu D Y, et al. SHRIMP U-Pb zircon dating of a metagabbro and eclogites from western Dabieshan (Hong'an block), China, and its tectonic implications. Tectonophysics, 2004, 394: 171192

6 Li S G, Li Q L, Hou Z H, et al. Cooling history and exhumation mechanism of the ultrahigh-pressure metamorphic rocks in the Dabie 
Mountains, central China. Acta Petrol Sin, 2005, 21: 1117-1124

7 Liu Y C, Li S G, Xu S T. Zircon SHRIMP U-Pb dating for gneisses in northern Dabie high T/P metamorphic zone, central China: Implications for decoupling within subducted continental crust. Lithos, 2007, 96: 170-185

8 Liu Y C, Li S G. Detachment within subducted continental crust and multi-slice successive exhumation of ultrahigh-pressure metamorphic rocks: Evidence from the Dabie-Sulu orogenic belt. Chin Sci Bull, 2008, 53: 3105-3119

9 Xu Z Q, Zeng L S, Liang F H, et al. A dynamic model for sequential subduction and exhumation of a continental slab: Age constraints on the timing of exhumation of the Sulu HP-UHP metamorphic terrane. Acta Petrol Mineral, 2005, 24: 852-863

10 Xu Z Q, Zeng L S, Liu F L, et al. Polyphase subduction and exhumation of the Sulu high-pressure-ultrahigh-pressure metamorphic terrane. Geol Soc Am Spec Pap, 2006, 403: 93-113

11 Liu F L, Gerdes A, Xue H M. Differential subduction and exhumation of crustal slices in the Sulu HP-UHP metamorphic terrane: Insights from mineral inclusions, trace elements, $\mathrm{U}-\mathrm{Pb}$ and $\mathrm{Lu}-\mathrm{Hf}$ isotope analyses of zircon in orthogneiss. J Metamorph Geol, 2009, 27: 805-825

12 Zheng Y-F. A perspective view on ultrahigh-pressure metamorphism and continental collision in the Dabie-Sulu orogenic belt. Chin Sci Bull, 2008, 53: 3081-3104

13 Liu X C, Jahn B M, Dong S W, et al. High-pressure metamorphic rocks from Tongbaishan, central China: $\mathrm{U}-\mathrm{Pb}$ and ${ }^{40} \mathrm{Ar} /{ }^{39} \mathrm{Ar}$ age constraints on the provenance of protoliths and timing of metamorphism. Lithos, 2008, 105: 301-318

14 Liu X C, Jahn B M, Cui J J, et al. Triassic retrograded eclogites and Cretaceous gneissic granites in the Tongbai Complex, central China: Implications for the architecture of the HP/UHP Tongbai-Dabie-Sulu collision zone. Lithos, 2010, 119: 211-237

15 Liu X C, Jahn B M, Li S Z, et al. The Tongbai HP metamorphic terrane: Constraints on the architecture and subduction/exhumation of the Tongbai-Dabie-Sulu HP/UHP metamorphic belt. Acta Petrol Sin, 2011, 27: 1151-1162

16 Hacker B R, Ratschbacher L, Webb L E, et al. Exhumation of ultrahigh-pressure continental crust in east central China: Late TriassicEarly Jurassic tectonic unroofing. J Geophys Res, 2000. 105: 1333913364

17 Liu Y C, Li S G, Gu X F, et al. Zircon SHRIMP U-Pb dating for olivine gabbro at Wangmuguan in the Beihuaiyang zone and its geological significance. Chin Sci Bull, 2006, 51: 2500-2506

18 Liu Y C, Liu L X, Gu X F, et al. Occurrence of Neoproterozoic lowgrade metagranite in the western Beihuaiyang zone, the Dabie orogen. Chin Sci Bull, 2010, 55: 3490-3498

19 Huang S Y, Xu B, Wang C Q, et al. Geometry, Kinematics and evolution of the Tongbai orogenic belt. Sci China Ser D-Earth Sci, 2006, 49: 828-838

20 Cheng $\mathrm{H}$ Zhang C, Vervoort J D, et al. New Lu-Hf geochronology constraints the onset of continental subduction in the Dabie orogen. Lithos, 2011, 121: 41-54

21 Webb L E, Hacker B R, Ratschbacher L, et al. Thermochronologic constraints on deformation and cooling history of high- and ultrahighpressure rocks in the Qinling-Dabie orogen, eastern China. Tectonics, 1999, 18: 621-638

22 Xu G, Wang E Q. The uplift mechanism of Tongbai complex in Mesozoic and its coupling relationship with Nanyang Basin. Chin J Geol, 2010, 45: 626-652

23 Cui J J, Liu X C, Dong S W, et al. U-Pb and ${ }^{40} \mathrm{Ar} /{ }^{39} \mathrm{Ar}$ geochronology of the Tongbai complex, central China: Implications for Cretaceous exhumation and lateral extrusion of the Tongbai-Dabie HP/ UHP terrane. J Asian Earth Sci, 2012, 47: 155-170

24 Liu X C, Kang W G, Zhou G Z, et al. Study of principal minerals and metamorphic evolution of blueschists in the south margin of the Tongbai-Dabie Mountains. J Changchun Univ Earth Sci, 1989, Special Issue: $41-56$

25 Li S Z, Kusky T M, Zhao G C, et al. Thermochronological constraints on two-stage extrusion of HP/UHP terranes in the Dabie-Sulu orogen, east-central China. Tectonophysics, 2011, 504: 25-42

26 Jahn B M, Liu X C, Yui T-F, et al. High-pressure/ultrahigh-pressure eclogites from the Hong'an Block, east-central China: Geochemical characterization, isotope disequilibrium and geochronological controversy. Contrib Mineral Petrol, 2005, 149: 499-526

27 Cheng H, King R L, Nakamura E, et al. Transitional time of oceanic to continental subduction in the Dabie orogen: Constraints from U-Pb, Lu-Hf, Sm-Nd and Ar-Ar multichronometric dating. Lithos, 2009, 110: $327-342$

28 Cheng H, DuFrane S A, Vervoort J D, et al. Protracted oceanic subduction prior to continental subduction: New $\mathrm{Lu}-\mathrm{Hf}$ and $\mathrm{Sm}-\mathrm{Nd}$ geochronology of oceanic-type high-pressure eclogite in the western Dabie orogen. Am Mineral, 2010, 95: 1214-1223

29 Cheng H, Zhang Z, Vervoort J D, et al. New Lu-Hf and Sm-Nd geochronology constraints the subduction of oceanic crust during the Carboniferous-Permian in the Dabie orogen. J Asian Earth Sci, 2013, 63: $139-150$

30 Sun W D, Williams I S, Li S G. Carboniferous and Triassic eclogites in the western Dabie Mountains, east-central China: Evidence for protracted convergence of the North and South China Blocks. J Metamorph Geol, 2002, 20: 873-886

31 Wu Y-B, Hanchar J M, Gao S, et al. Age and nature of eclogites in the Huwan shear zone, and the multi-stage evolution of the QinlingDabie-Sulu orogen, central China. Earth Planet Sci Lett, 2009, 277: 345-354

32 Liu X C, Wu Y B, Gao S, et al. Zircon U-Pb and Hf evidence for coupled subduction of oceanic and continental crust during the Carboniferous in the Huwan shear zone, western Dabie orogen, central China. J Metamorph Geol, 2011, 29: 233-249

33 Niu B G, Fu Y L, Liu Z G, et al. Main tectonothermal events and ${ }^{40} \mathrm{Ar} /{ }^{39} \mathrm{Ar}$ dating of the Tongbai-Dabie Mts. Acta Geosci Sin, 1994, 15: 20-34

34 Faure M, Lin W, Schärer U, et al. Continental subduction and exhumation of the UHP rocks. Structural and geochronological insights from the Dabieshan (East China). Lithos, 2003, 70: 213-241

35 Ratschbacher L, Franz L, Enkelmann E, et al. The Sino-KoreanYangtze suture, the Huwan detachment, and the Paleozoic-Tertiary exhumation of (ultra)high-pressure rocks along the Tongbai-XinxianDabie Mountains. In: Hacker B R, McClelland W C, Liou J G, eds. Ultrahigh-pressure Metamorphism: Deep Continental Subduction. Geol Soc Am Spec Pap, 2006, 403: 45-75

36 Zhou J B, Zheng Y-F, Li L, et al. Accretionary wedge of the subduction of the Yangtze plate. Acta Geol Sin, 2001, 75: 338-352

37 Zheng Y-F, Zhou J-B, Wu Y-B, et al. Low-grade metamorphic rocks in the Dabie-Sulu orogenic belt: A passive-margin accretionary wedge deformed during continent subduction. Inter Geol Rev, 2005, 47: $851-871$

38 Liu X C, Jahn B M, Li S Z, et al. U-Pb zircon age and geochemical constraints on tectonic evolution of the Paleozoic accretionary orogenic system in the Tongbai orogen, central China. Tectonophysics, 2013, 599: 67-88

39 Liu X C, Jahn B M, Hu J, et al. Metamorphic patterns and SHRIMP zircon ages of medium-to-high grade rocks from the Tongbai orogen, central China: Implications for multiple accretion/collision processes prior to terminal continental collision. J Metamorph Geol, 2011, 29: 979-1002

40 Zhang $\mathrm{H} \mathrm{F}$, Zhang B, Zhong Z Q, et al. Pb isotopic geochemical study on the crustal structure of Tongbai Shan. Prog Nat Sci, 2003, 13: 63-68

41 Li S G, Han W, Huang F, et al. Sm-Nd and Rb-Sr ages and geochemistry of volcanics from the Dingyuan formation in Dabie Mountains, central China: Evidence to the Paleozoic magmatic arc. Sci Geol Sin, 1998, 7: 461-470

42 Zheng Y-F. Metamorphic chemical geodynamics in continental subduction zones. Chem Geol, 2012, 328: 5-48

43 Liu X, Li S Z, Suo Y H, et al. Structural anatomy of the exhumation of high-pressure rocks: Constraints from the Tongbai Collisional Orogen and surrounding units. Geol J, 2011, 46: 156-172

44 Liu X C, Wu Y B, Gao S, et al. Triassic high-pressure metamorphism 
in the Huwan shear zone: Tracking the initial subduction of continental crust in the whole Dabie orogen. Lithos, 2012, 136-139: 60-72

45 Cheng H, DuFrane S A, Vervoort J D, et al. The Triassic age for oceanic eclogites in the Dabie orogen: Entrainment of oceanic fragments in the continental subduction. Lithos, 2010, 117: 82-98

46 Wu Y-B, Zheng Y-F, Zhao Z-F, et al. U-Pb, Hf and O isotope evidence for two episodes of fluid-assisted zircon growth in marblehosted eclogites from the Dabie orogen. Geochim Cosmochim Acta, 2006, 70: 3743-3761

47 Liu F L, Gerdes A, Liou J G, et al. SHRIMP U-Pb zircon dating from Sulu-Dabie dolomitic marble, eastern China: Constraints on prograde, ultrahigh-pressure and retrograde metamorphic ages. J Metamorph Geol, 2006, 24: 569-589

48 Liu D Y, Jian P, Kröner A, et al. Dating of prograde metamorphic events deciphered from episodic zircon growth in rocks of the DabieSulu UHP complex, China. Earth Planet Sci Lett, 2006, 250: 650-666

49 Liu F L, Liou J G. Zircon as the best mineral for $P$ - $T$-time history of UHP metamorphism: A review on mineral inclusions and U-Pb SHRIMP ages of zircons from the Dabie-Sulu UHP rocks. J Asian Earth Sci, 2011, 40: 1-39

50 Zheng Y-F, Chen R-X, Zhao Z-F. Chemical geodynamics of conti- nental subduction-zone metamorphism: Insights from studies of the Chinese Continental Scientific Drilling (CCSD) core samples. Tectonophysics, 2009, 475: 327-358

51 Liu Y C, Gu X F, Li S G, et al. Multistage metamorphic events in granulitized eclogites from the North Dabie complex zone, central China: Evidence from zircon $\mathrm{U}-\mathrm{Pb}$ age, trace element and mineral inclusion. Lithos, 2011, 122: 107-121

52 Lin W, Wang J, Liu F, et al. Late Mesozoic extension structures on the North China Craton and adjacent regions and its geodynamics. Acta Petrol Sin, 2013, 29: 1791-1810

53 Zhao Z F, Zheng Y-F, Wei C S, et al. Zircon U-Pb ages, Hf and $\mathrm{O}$ isotopes constrain the crustal architecture of the ultrahigh-pressure Dabie orogen in China. Chem Geol, 2008, 253: 222-242

54 Zhao Z F, Zheng Y-F, Wei C S, et al. Origin of postcollisional magmatic rocks in the Dabie orogen: Implications for crust-mantle interaction and crustal architecture. Lithos, 2011, 126: 99-114

55 Zhao X X, Coe R S. Paleomagnetic constraints on the collision and rotation of north and south China. Nature, 1987, 327: 141-144

56 Enkin R J, Courtillot V, Leloup Ph, et al. The paleomagnetic record of Uppermost Permian, Lower Triassic rocks from the South China Block. Geophys Res Lett, 1992, 19: 2147-2150

Open Access This article is distributed under the terms of the Creative Commons Attribution License which permits any use, distribution, and reproduction in any medium, provided the original author(s) and source are credited. 